\title{
Pengaruh Pemberian Limbah Singkong Terfermentasi Dan Mineral Mikro Organik Dalam Ransum Terhadap Penampilan Kambing
}

\author{
K. Adhianto*, Muhtarudin, A. Husni, M. F. Zhahir \\ Jurusan Peternakan, Fakultas Pertanian, Universitas Lampung, Lampung, Indonesia 35145 \\ Dikirim 21 Maret 2019; Diterima 02 September 2019
}

\begin{abstract}
ABSTRAK
Penelitian ini bertujuan untuk mengetahui pengaruh pemberian limbah singkong terhadap performa kambing PE jantan. Penelitian dilaksanakan di Kandang Jurusan Peternakan, Fakultas Pertanian, Universitas Lampung pada Mei sampai dengan Agustus 2018. Percobaan in vivo dilakukan pada 12 ekor kambing PE jantan bobot berkisar 25-30 kg, dengan Rancangan Acak Kelompok (RAK) yang terdiri dari 4 perlakuan dan 3 kelompok sebagai ulangan. Perlakuan dalam penelitian ini yaitu R0: ransum basal $+30 \%$ onggok basah tidak terolah, $\mathrm{R} 1$ : ransum basal $+30 \%$ onggok terfermentasi dengan ragi tape, $\mathrm{R} 2$ : $\mathrm{R} 1+$ 15\% daun singkong, dan R3: R2 + mineral mikro organik. Data yang diperoleh dianalisis dengan menghitung rataan tiap perlakuan untuk menentukan pengaruh jenis ransum yang terbaik terhadap pertambahan bobot tubuh, konsumsi, konversi, dan efisiensi ransum. Hasil penelitian ini menunjukan pemberian ransum R2 memiliki hasil rata-rata tertinggi dengan meningkatkan bobot tubuh sebesar 0,15 kg/ekor/hari, konversi sebesar 13,03, dan efisiensi sebesar 7,83 serta konsumsi ransum dalam BK sebesar 1,98 kg/hari. Pemberian ransum R0 memiliki hasil terendah dengan hanya meningkatkan bobot tubuh sebesar 0,11 $\mathrm{kg} / \mathrm{ekor} / \mathrm{hari}$, konversi sebesar 18,55, dan efisiensi sebesar 5,48 serta konsumsi ransum dalam BK sebesar 1,96 kg/hari. Kesimpulan penggunaan limbah singkong terfermentasi dan mineral mikro organik pada ransum terbaik yaitu pada R2 terhadap pertambahan bobot tubuh, konversi ransum, efisiensi dan konsumsi BK ransum.
\end{abstract}

Kata kunci: Kambing PE, Onggok basah, Mineral mikro organik, Performa

\section{Effect of Fermented Cassava Waste And Organic Micro Minerals In Rations Against Performance of Goats}

\begin{abstract}
This study aims to determine the effect of cassava waste on male etawa crossbred goat performance (consumption, body weight gain, ration conversion, and ration efficiency). The study was conducted at goat pen in Department of Animal Husbandry, Faculty of Agriculture, University of Lampung from May to August 2018. In vivo experiments were carried out on 12 male etawa crossbred goat, with a Randomized Block Design (RBD) consisting of 4 treatments and 3 replications. The treatments in this study were R0: basal ration $+30 \%$ unprocessed wet cassava waste, R1: basal ration $+30 \%$ fermented onggok with tapai yeast, $R 2: R 1+15 \%$ cassava leaves (a source of branched chain amino acids), and $R 3: R 2+$ organic micro minerals $(\mathrm{Zn}, \mathrm{Cu}, \mathrm{Se}, \mathrm{Cr})$. The data obtained were analyzed by calculating the average of each treatment to determine the effect of the best type of ration on each parameter. The results of this study showed that $R 2$ ration had the highest results of increasing body weight by $0.15 \mathrm{~kg} / \mathrm{head} / \mathrm{day}$, ration conversion 13,03, and efficiency 7,83 and dry matter intake by 1,98 $\mathrm{kg} / \mathrm{day}$. The RO ration had the lowest results of increasing body weight by $0.11 \mathrm{~kg} / \mathrm{head} / \mathrm{day}$, ration conversion by 18,55 , and efficiency by 5,48 and feed consumption in dry matter by $1,96 \mathrm{~kg} /$ day. Conclusion, the used of fermented cassava waste and organic micro minerals in the best ration that is in $R 2$ to body weight gain, feed conversion, efficiency and dry matter intake.
\end{abstract}

Keywords: Etawa goat grade, Cassava waste, Organic micro minerals, Ration

\section{PENDAHULUAN}

Limbah tanaman singkong sangat potensial sebagai pakan ternak alternatif, karena ketersediaannya banyak dan tidak bersaing dengan kebutuhan manusia. Salah satu kendala yang dihadapi limbah tanaman singkong adalah nilai gizi yang rendah, seperti protein rendah dan serat kasar yang tinggi. Hal ini berdampak pada kecernaannya menjadi rendah, yang pada akhirnya dapat mengganggu penampilan ternak.

Onggok adalah limbah singkong yang memiliki potensi sangat besar. Onggok telah banyak dimanfaatkan untuk pakan ruminansia. Salah satu kelemahan dari onggok sebagai pakan ruminansia

\footnotetext{
*Penulis Korespondensi: Dr. Kusuma Adhianto, S.Pt., M.P.

Alamat: J1. Soemantri Brojonegoro 1, Gedong Meneng, Bandar

Lampung, 35145

E-mail: kusuma_adhianto@fp.unila.ac.id
}

adalah kandungan protein yang rendah. Untuk meningkatkan manfaat dari onggok (terutama protein) maka perlu dilakukan pengolahan. Metode pengolahan yang biasa digunakan untuk meningkatkan nilai dan kualitas protein adalah dengan fermentasi. Peningkatan protein dalam fermentasi akan berhasil apabila jenis kapang dan yeast serta prekursor dipilih dengan tepat untuk terjadinya biokonversi zat-zat prekursor menjadi protein yang berkualitas (protein mikroba atau protein bahan). Pemilihan jenis kapang dan yeast serta prekursor yang tepat dapat dipilih melalui penelitian in vitro sebelum dilakukan penelitian secara in vivo pada ternak ruminansia. Amonium sulfat dan urea dapat dipilih menjadi prekursor untuk menjadi sumber nitrogen sebagai salah satu prekursor dari biokonversi protein. Amonium sulfat selain menyumbang nitrogen juga dapat menyumbang sulfur sebagai salah satu prekursor untuk asam amino yang mengandung sulfur. Sulfur organik dan anorganik dapat dimanfaatkan oleh 
mikroba sebagai komponen pembentuk metionin, sistin, dan sistein. Selain itu Sulfur merupakan sumber komponen vitamin tiamin dan biotin. Asam amino yang mengandung sulfur disintesis de novo dari pul sulfida rumen. Penggunaan nitrogen bukan protein dalam jumlah besar mengakibatkan keterbatasan sulfur, sehingga penambahan sulfur harus dipertimbangkan.

Fraksi limbah singkong lainnya yang memiliki nilai gizi yang baik adalah daun singkong. Daun singkong mempunyai protein yang tinggi dan beberapa asam aminonya dapat digunakan sebagai sumber asam amino pembatas pada ternak ruminansia. Daun singkong merupakan bahan pakan alami yang dapat digunakan sebagai sumber BCAA (Branch Chain Amino Acid). Kandungan BCAA daun singkong melebihi kandungan BCAA tepung ikan maupun bungkil kelapa. Kelebihan lain tepung daun singkong adalah sangat mudah didegradasi oleh mikroba rumen. Untuk sintesis protein mikroba diperlukan asam lemak rantai cabang (BCFA; branched-chain fatty acids) yang meliputi asam isobutirat, metilbutirat, dan isovalerat. BCFA dalam rumen adalah hasil dekarboksilasi dan deaminasi asam amino rantai cabang (BCAA) yaitu valin, isoleusin, dan leusin. Selain itu mikroba rumen yang lisis di dalam rumen juga menyumbang terhadap pul BCFA rumen. Apabila pasokan dari dua sumber tersebut tidak mencukupi maka diperlukan suplementasi asam lemak bercabang atau asam amino rantai cabang. Suplementasi BCAA memacu pertumbuhan bakteri sehingga kecernaan pakan dan pertumbuhan ternak meningkat (Muhtarudin et al., 2016).

Optimalisasi penggunaan limbah pertanian seperti limbah singkong harus didukung oleh teknologi lain dalam upaya memanipulasi bioproses rumen dan pasca rumen. Optimalisasi bioproses rumen dan pasca rumen dapat tercapai jika semua prekursor mikroba dalam rumen dan keseimbangan zat makanan pasca rumen terpenuhi Bioproses dalam rumen dan pasca rumen harus didukung kecukupan meneral makro dan mikro. Mineral-mineral ini berperan dalam optimalisasi bioproses dalam rumen dan metabolisme zat-zat makanan.

Mineral mikro dan makro di dalam alat pencernaan ternak dapat saling berinteraksi positif atau negatif dan faktor lainnya seperti asam fitat, serat kasar, dan zat-zat lainnya dapat menurunkan ketersediaan mineral. Pemberian mineral dalam bentuk organik dapat meningkatkan ketersediaan sehingga dapat lebih tinggi diserap dalam tubuh ternak (Muhtarudin, 2003). Mineral dalam bentuk chelates dapat lebih tersedia diserap dalam proses pencernaan. Agensia chelating dapat berupa karbohidrat, lipid, asam amino, fosfat, dan vitamin. Dalam proses pencernaan chelates dalam ransum memfasilitasi menembus dinding sel usus. Secara teoritis, chelates meningkatkan penyerapan mineral (Muhtarudin et al., 2018).

Berdasarkan uraian tersebut, penulis melakukan penelitian untuk mengetahui pengaruh pemberian pakan limbah Singkong, mineral mikro organik dan asam amino pembatas terhadap performa (konsumsi, pertambahan bobot tubuh, konversi, dan efisiensi ransum) kambing PE jantan.

\section{MATERI DAN METODE}

\section{Waktu dan Tempat Penelitian}

Penelitian ini dilaksanakan pada bulan MeiAgustus 2018, bertempat di kandang Jurusan Peternakan, Fakultas Pertanian, Universitas Lampung.

\section{Materi Penelitian}

Materi penelitian yang digunakan pada penelitian ini berupa 12 ekor kambing PE jantan dengan bobot berkisar $25 \mathrm{sd} 30 \mathrm{~kg}$, setiap 4 ekor kambing mendapat perlakuan ransum yang berbeda. Ransum perlakuan (R0, R1, R2, R3) dengan penggunaan ransum limbah singkong (onggok basah dan daun singkong), mineral organik, tebon jagung dan bungkil sawit.

\section{Alat}

Peralatan yang digunakan adalah kandang individual berkapasitas 12 ekor kambing, timbangan digital, timbangan gantung, dan timbangan duduk.

\section{Metode Penelitian}

Penelitian in vivo dilakukan pada 12 ekor kambing PE jantan, dengan Rancangan Acak Kelompok (RAK) yang terdiri dari 4 perlakuan dan 3 kelompok sebagai ulangan. Pengelompokan dibuat berdasarkan bobot tubuh.

a. R0: Ransum basal $+30 \%$ Onggok tidak terolah

b. R1: Ransum basal $+30 \%$ Onggok terfermentasi

c. R2: R1 $+15 \%$ daun singkong (sumber asam amino bercabang/brand chain fatty acids)

d. R3: R2 + Mineral mikro organik (Zn, Cu, Se, Cr)

\section{Analisis Data}

Data yang diperoleh dianalisis deskrisptif dengan menghitung rataan tiap perlakuan untuk menentukan pengaruh jenis ransum yang terbaik terhadap masingmasing parameter.

\section{Peubah yang Diamati}

Peubah yang diamati pada penelitian ini adalah pertambahan bobot tubuh, konsumsi, konversi, dan efisiensi ransum.

\section{HASIL DAN PEMBAHASAN}

\section{Pertambahan Bobot Tubuh}

Pertambahan bobot tubuh merupakan salah satu kriteria yang dapat digunakan untuk mengevaluasi kualitas bahan makanan ternak, karena pertumbuhan yang diperoleh dari suatu percobaan merupakan salah satu indikasi pemanfaatan zat-zat makanan dari pakan yang diberikan (Hatmono dan Hastoro, 1997). Rataan pertambahan bobot tubuh selma penelitian dapat dilihat pada Tabel 1. 
Hasil pada penelitian ini diperoleh bahwa pemberian limbah singkong fermentasi dan mineral mikro organik dapat meningkatkan pertambahan bobot tubuh harian. Dari hasil penelitian terlihat bahwa pertambahan bobot tubuh R2 dan R3 lebih tinggi dibanding R0 dan R1. Sedangkan menurut Hafid (2002) pertambahan bobot badan ternak sangat dipengaruhi oleh jenis ternak, jenis kelamin, umur, pakan, faktor lingkungan dan pemeliharaan.

Hal ini sesuai dengan pendapat Tanwiri et al. (2006) bahwa jumlah konsumsi ransum yang banyak menunjukkan jumlah nutrisi yang diserap untuk kebutuhan hidup pokok, produksi, dan reproduksi meningkat sehingga menyebabkan pertumbuhan yang meningkat juga. Kartadisastra (1997), menambahkan bahwa bobot tubuh ternak senantiasa berbanding lurus dengan konsumsi ransum, makin tinggi bobot tubuhnya, makin tinggi pula tingkat konsumsinya terhadap ransum. Menurut Mulyono dan Sarwono (2005), pertambahan bobot kambing yang digemukkan secara intensif bisa mencapai 100-150 gram per hari dengan rata-rata 120 gram per hari.

Septian et al. (2015) berpendapat bahwa pola pertambahan bobot badan kambing Kacang jantan membentuk pola sigmoid (S). Pada umur 8 bulan pertumbuhan bobot badan kambing Kacang jantan mengalami pertumbuhan yang sangat cepat, karena pada umur tersebut kambing Kacang jantan belum dewasa kelamin, sedangkan pada umur 9-42 bulan pertumbuhannya mengalami perlambatan, karena ternak sudah dewasa tubuh dan pertumbuhan ternak saat itu tidak hanya digunakan untuk pertambahan bobot badan saja melainkan juga digunakan untuk reproduksi juga.

Hal ini sesuai dengan Sampurna dan Suatha (2010), bahwa pertumbuhan mempunyai tahap-tahap yang cepat dan lambat, tahap cepat terjadi pada saat ternak belum dewasa kelamin, dan tahap lambat terjadi pada saat dewasa tubuh tercapai. Menurut Soeparno (2009) kambing mencapai dewasa kelamin pada umur 6-10 bulan. Hormon testosteron yang mulai diproduksi setelah dewasa kelamin mempengaruhi laju pertambahan bobot badan. Hormon testosteron menstimulasi sintesis protein otot (Utomo et al., 2006).

Church dan Pond (1988) menyatakan bahwa semakin baik kualitas ransum yang diberikan maka akan diikuti dengan pertambahan bobot tubuh yang lebih tinggi. Pada Tabel 1 dapat di lihat bahwa hasil

Tabel 1. Pertambahan bobot tubuh kambing PE jantan (kg/ekor/hari)

\begin{tabular}{ccccc}
\hline \hline $\begin{array}{c}\text { Ulangan/ } \\
\text { Perlakuan }\end{array}$ & R0 & R1 & R2 & R3 \\
\hline K1 & 0,11 & 0,09 & 0,17 & 0,14 \\
K2 & 0,09 & 0,14 & 0,14 & 0,13 \\
K3 & 0,12 & 0,15 & 0,15 & 0,18 \\
\hline Rataan & $0,11+0,02$ & $0,13+0,03$ & $0,15+0,02$ & $0,15+0,03$
\end{tabular}

R0 = Ransum basal + 30\% Onggok tidak terolah;R1 = Ransum basal $+30 \%$ Onggok terfermentasi;R2 $=\mathrm{R} 1+15 \%$ daun singkong (sumber asam amino bercabang/brand chain fatty acids);R3 = R2 + Mineral mikro organik $(\mathrm{Zn}, \mathrm{Cu}, \mathrm{Se}, \mathrm{Cr})$ tertinggi di tunjukan pada perlakuan R2 dan R3 yaitu 0,15 . Perbedaan antara perlakuan R2 dan R3 terdapat hanya pada penambahan mineral mikroorganik, sehingga dapat dikatakan bahwa mineral mikro organik tidak berpengaruh pada penelitian ini.

Namun menurut Vandergrift (1992), mineral organik dapat langsung diserap karena terikat dengan asam-asam amino maupun senyawa organik lainnya. Penggunaan mineral organik selain dapat meningkatkan efisiensi pakan dengan ketersediaan mineral yang lebih baik, dapat pula meningkatkan kekebalan, mengatasi stress, dan meningkatkan reproduksi ternak. Pengaruh mineral makro dan mikro organik dievaluasi secara in vitro dan in vivo pada kambing pada tahun 2005, hasilnya memberikan pengaruh yang nyata terhadap peningkatan bioproses rumen (nilai VFA dan NH3), kecernaan (kecernaan bahan kering, bahan organik, serta energi).

Pada perlakuan R2 dan R3 terdapat limbah daun singkong yang tidak terdapat pada perlakuan R0 dan $\mathrm{R} 1$, daun singkong ini digunakan sebagai sumber hijauan dan asam amino bercabang. Tabel 1 menunjukan bahwa ransum yang menggunakan pakan hijauan tambahan berupa daun singkong memberikan pertambahan bobot tubuh tertinggi dibandingkan dengan ransum yang menggunakan pakan hijauan berupa tebon jagung saja. Perbedaan pertambahan bobot tubuh kambing Peranakan Etawa diduga disebabkan adanya komposisi asam amino berupa metionin yang lebih tinggi yang berasal dari daun singkong. Purba et al. (2017) juga melaporkan bahwa penambahan daun singkong dalam ransum dapat meningkatkan kecernaan serat kasar dan protein kasar, sehingga ransum dapat optimal dimanfaatkan oleh ternak.

\section{Konsumsi Ransum}

Konsumsi ransum adalah jumlah makanan yang dikonsumsi oleh ternak digunakan untuk mencukupi hidup pokok dan untuk produksi hewan tersebut (Tillman et al., 1991). Rata-rata konsumsi ransum kambing selama penelitian ditampilkan pada Tabel 2.

Hasil pada penelitian ini diperoleh bahwa pemberian limbah singkong terfermentasi dan mineral mikro organik memiliki konsumsi ransum yanglebih tinggi pada R2 dan R3. Hal ini dikarenakan pada perlakuan R2 dan R3 terdapat daun singkong yang terfermentasi dan onggok basah yang terfermentasi

Tabel 2. Konsumsi ransum pada kambing PE jantan (kg/ekor/hari)

\begin{tabular}{ccccc}
\hline \hline Perlakuan & R0 & R1 & R2 & R3 \\
\hline U1 & 1,74 & 1,77 & 1,79 & 1,66 \\
U2 & 1,95 & 1,92 & 1,97 & 1,99 \\
U3 & 2,18 & 2,11 & 2,17 & 2,26 \\
\hline Rataan & $1,96 \pm 0,22$ & $1,93 \pm 0,17$ & $1,98 \pm 0,19$ & $1,97 \pm 0,30$
\end{tabular}

R0 = Ransum basal + 30\% Onggok tidak terolah; R1 = Ransum basal $+30 \%$ Onggok terfermentasi; $\mathrm{R} 2=\mathrm{R} 1+15 \%$ daun singkong (sumber asam amino bercabang/brand chain fatty acids); R3 = R2 + Mineral mikro organik ( $\mathrm{Zn}, \mathrm{Cu}, \mathrm{Se}, \mathrm{Cr})$. 
yang membuat ransum memiliki aroma, tekstur dan rasa yang lebih baik dibandingkan dengan perlakuan R0 dan R1 yang menggunakan onggok tidak terolah dan tebon jagung sebagai sumber hijauan.

Onggok yang terfermentasi memiliki aroma yang lebih menarik dibandingkan dengan onggok yang tidak terfermentasi, karena onggok yang tidak terfermentasi memiliki aroma asam yang mungkin tidak disukai oleh kambing PE, hal ini sejalan dengan pernyataan Devendra dan Burns (1994), yang menyatakan bahwa pada umumnya kambing merupakan jenis ternak yang mempunyai kebiasaan memilih pakan yang akan dikonsumsinya dan pada ternak ruminansia rangsangan penciuman (bau/aroma) sangat penting untuk mencari dan memilih makanan. Berdasarkan hasil penelitian Septiani et al. (2013) dinyatakan bahwa ransum dengan suplementasi mineral organik tidak berpengaruh nyata terhadap kecernaan bahan kering (KCBK) dan kecernaan bahan organik (KCBO) pada kambing.

\section{Konversi Ransum}

Konversi ransum adalah jumlah pakan yang dikonsumsi per hari dibagi pertambahan bobot hidup harian. Konversi ransum dapat digunakan untuk mengetahui efisiensi produksi karena erat kaitannya dengan biaya produksi, semakin rendah nilai konversi ransum maka efisiensi penggunaan ransum semakin tinggi, hal ini merupakan kebalikan dari efisiensi ransum yaitu semakin tinggi nilai efisiensi ransum maka jumlah pakan yang diperlukan untuk menghasilkan satu kilogram daging semakin sedikit. Rata-rata konversi ransum kambing selama penelitian ditampilkan pada Tabel 3.

Hasil pada penelitian ini diperoleh bahwa pemberian limbah singkong fermentasi dan mineral mikro organik (R2 dan R3) memiliki konversi ransum yang lebih baik dibandingkan R0 dan R1. Pada Tabel 3 nilai konversi tertinggi diperoleh dari hasil perlakuan R0 yaitu 18,55 yang menghasilkan pertambahan bobot tubuh $0,11 \mathrm{~kg}$ (Tabel 1) dan nilai terendah diperoleh dari hasil perlakuan R2 yaitu 13,03 yang menghasilkan pertambahan bobot tubuh $0,15 \mathrm{~kg}$ (Tabel 1). Semakin rendahnya nilai konversi rans um maka semakin efisien dan menghasilkan bobot tubuh yang lebih baik. Konversi ransum dapat digunakan untuk mengetahui efisiensi produksi karena erat kaitannya dengan biaya produksi.

Tabel 3. Rataan konversi ransum kambing PE jantan

\begin{tabular}{ccccc}
\hline Perlakuan & R0 & R1 & R2 & R3 \\
\hline U1 & 15,83 & 19,67 & 10,54 & 11,86 \\
U2 & 21,63 & 13,73 & 14,08 & 15,27 \\
U3 & 18,18 & 14,08 & 14,48 & 12,57 \\
\hline Rataan & $18,55 \pm 2,92$ & $15,83 \pm 3,33$ & $13,03 \pm 2,17$ & $13,23 \pm 1,80$
\end{tabular}

R0 = Ransum basal + 30\% Onggok tidak terolah; R1 = Ransum basal $+30 \%$ Onggok terfermentasi; R2 $=\mathrm{R} 1+15 \%$ daun singkong (sumber asam amino bercabang/brand chain fatty acids); R3 = R2 + Mineral mikro organik ( $\mathrm{Zn}, \mathrm{Cu}, \mathrm{Se}, \mathrm{Cr})$
Juarini et al. (1995), menyatakan bahwa semakin tinggi nilai konversi ransum berarti ransum yang digunakan untuk menaikkan bobot badan persatuan berat semakin banyak atau efisiensi ransum rendah. Perry et al. (2005), menambahkan bahwa konversi ransum merupakan jumlah ransum yang dikonsumsi untuk mendapatkan kenaikan satu satuan bobot hidup. Kemudian dikatakan bahwa tingginya konversi ransum dapat terkait dengan kandungan serat kasar ransum. Serat kasar yang tinggi dalam ransum akan menyebabkan daya cerna menjadi kecil, sehingga konversi ransum merupakan integrasi dari daya cerna (Anggorodi, 1994).

\section{Efisiensi Ransum}

Efisiensi ransum adalah perbandingan antara pertambahan bobot badan yang dihasilkan dengan jumlah ransum yang di konsumsi. Kualitas ransum merupakan salah satu faktor yang mempengaruhi efisiensi penggunaan ransum, semakin rendah nilai gizi dalam ransum, maka semakin rendah pula efisiensi penggunaan ransum (Tillman et al., 1991). Jumlah zat gizi yang dibutuhkan dan kemampuan mengkonsumsi ransum bagi ternak ruminansia akan sangat tergantung pada bobot badan ternak bersangkutan (Siregar, 1994). Semakin tinggi nilai gizi dalam ransum, maka konversi ransum akan semakin rendah sehingga menunjukkan efisiensi penggunaan ransum menjadi lebih baik (Maynard et al., 1979). Pertambahan bobot badan yang tinggi maka nilai konversi semakin rendah dan semakin efisien ransum yang digunakan (Pond et al., 1995). Rata-rata efisiensi ransum kambing selama penelitian ditampilkan pada Tabel 4.

Hasil pada penelitian ini diperoleh bahwa pemberian limbah singkong fermentasi dan mineral mikro organik nilai efisiensi ransum R2 dan R3 lebih tinggi dari R0 dan R1. Semakin tinggi nilai efisiensi ransum sehingga semakin efisien dan menghasilkan bobot tubuh yang baik dan konversi ransum sebaliknya semakin rendah nilai konversi ransum maka semakin efisien dan menghasilkan bobot tubuh yang lebih baik. Konversi ransum dapat digunakan untuk mengetahui efisiensi produksi karena erat kaitannya dengan biaya produksi. Tarmidi (2004) menambahkan bahwa selain konsumsi ransum dan pertambahan bobot badan, kualitas dan kuantitas dari ransum juga mempengaruhi, karena zat-zat yang dapat dicerna dalam ransum tersebut.

Tabel 4. Rataan efisiensi ransum kambing PE jantan (\%)

\begin{tabular}{ccccc}
\hline \hline Perlakuan & R0 & R1 & R2 & R3 \\
\hline U1 & 6,32 & 5,08 & 9,49 & 8,43 \\
U2 & 4,62 & 7,28 & 7,10 & 6,55 \\
U3 & 5,50 & 7,10 & 6,91 & 7,96 \\
\hline Rataan SD & $5,48 \pm 0,85$ & $6,49 \pm 1,22$ & $7,83 \pm 1,44$ & $7,65 \pm 0,98$
\end{tabular}

R0 = Ransum basal + 30\% Onggok tidak terolah; R1 = Ransum basal $+30 \%$ Onggok terfermentasi; R2 $=\mathrm{R} 1+15 \%$ daun singkong (sumber asam amino bercabang/brand chain fatty acids); R3 = R2 + Mineral mikro organik (Zn, Cu, Se, Cr). 


\section{KESIMPULAN}

Berdasarkan penelitian yang telah dilakukan dapat disimpulkan bahwa penggunaan limbah singkong terfermentasi dan mineral mikro organik memiliki nilai terbaik pada pertambahan bobot tubuh, konversi ransum, efisiensi dan konsumsi BK ransum.

\section{DAFTAR PUSTAKA}

Anggorodi. 1994. Ilmu Makanan Ternak Umum. Gramedia. Jakarta.

Church, D. C. and W. G. Pond. 1988. Basic Animal Nutrition and Feeding. 2nd ed. Jhon Willey and Sons. New York.

Devendra dan Burns. 1994. Produksi kambing di daerah Tropis. Institut Teknologi Bandung. Bandung.

Hafid, H. H. 2002. Pengaruh pertumbuhan kompensasi terhadap efisiensi pertumbuhan sapi Brahman Cross kebiri pada penggemukan feedlot. Agroland : Jurnal Ilmu-ilmu Pertanian 9: 179-185.

Hatmono. H. dan I. Hastoro. 1997. Urea Molases Block Pakan Suplemen Ternak Ruminansia. Trubus Agriwijaya. Ungaran.

Juarini, E. I. I. Hasan, B. Wibowo dan A. Tahar. 1995. Penggunaan konsentrat komersial dalam ransum domba di pedesaan dengan agroekosistem campuran (sawah tegalan) di Jawa Barat. Dalam : Prosiding Seminar Nasional Sains dan Teknologi Peternakan. Balai Penelitian Ternak. Bogor. pp. 176-181.

Kartadisastra, H. R. 1997. Penyediaan dan Pengolahan Pakan Ternak Ruminansia. Kanisius. Yogyakarta.

Maynard, L. A., J. K. Loosli, H. F. Hinz and K. G. Warner, 1979. Animal Nutritions. 7th ed. TMH Ed. Tata Mc.Graw-Hill Book Company. Inc. New York.

Muhtarudin. 2003. Pembuatan dan penggunaan ZnProteinat dalam ransum untuk meningkatkan nilai hayati dedak gandum dan optimalisasi bioproses dalam pencernaan ternak kambing. Jurnal Penelitian Pertanian Terapan 3(5): 385-393.

Muhtarudin, Y. Widodo, Liman, and K.Adhianto. 2016. Utilization of Micro-Organic Minerals in Feed Based on Agroindustry by Products to Improve Ruminant Production. Pakistan Journal of Nutrition 15(9): 846-848.

Muhtarudin., Liman, I. C. A. Permana, I. Pangestika, G. A. Wijianto, E. Susanti and K. Adhianto. 2018. The Effect Of Rations Based On Palm Oil ByProducts On Rumen Parameters And Digestibility In Ongole Cattle. Pakistan Journal of Nutrition 17(12): 622-626.

NRC (National Research Council). 1989. Nutrient Requirement of Dairy Cattle.6th ed. National Academy Press. Washington D.C.

Perry, T. W., A. E. Cullison and R. S. Lowrey. 2005. Feed and Feeding. 6th ed. Pearson Education, Inc. Upper SaddleRiver. New Jersey.
Pond, W. G., D. C. Church and K. R. Pond. 1995. Basic Animal Nutrition and Feeding. 4th ed. John Willey and Sons, Canada.

Prawirokusumo, S., Nasrudin dan Umiyeni. 1987. Suplementasi Methionin Pada Ransum Ayam Pedaging Berkadar Cassava Tinggi. Dalam : Prosiding Seminar Penelitian Peternakan. Fakultas Peternakan. Universitas Gajah Mada. Yogyakarta.

Purba. E. P., Erwanto, dan Liman. 2017. Pengaruh Penambahan Silase Daun Singkong Dan Mineral Mikro Organik Dalam Ransum Berbasis Limbah Kelapa Sawit Terhadap Kecernaan Serat Kasar Dan Protein Kasar. Jurnal Riset dan Inovasi Peternakan. 1(1): 16-19.

Sampurna. I. P. dan I. K. Suatha. 2010. Pertumbuhan alometri dimensi panjang dan lingkar tubuh sapi bali jantan. Jurnal Veteriner. 11(1): 46- 51.

Septian. A. D., M. Arifin dan E. Rianto. 2015. Pola Pertumbuhan Kambing Kacang Jantan di Kabupaten Grobogan. Animal Agriculture Journal 4(1): 1-6.

Septiani. V., Muhatarudin, dan Y. Widodo. 2013. Optimalisasi Pemanfaatan Limbah Agroindustri Melalui Suplementasi Mineral $\mathrm{Ca}$ dan $\mathrm{Mg}$ Organik Terhadap KCBK dan KCBO Ransum Kambing. Jurnal Ilmiah Peternakan Terpadu. 1(2): 21-26.

Siregar, S. 1994. Ransum Ternak Ruminansia. Penebar Swadaya. Jakarta.

Soeparno, 2009. Ilmu dan Teknologi Daging. Cetakan V. Gadjah Mada University Press. Yogyakarta.

Suarni dan S. Widowati. 2007. Struktur, komposisi, dan nutrisi jagung. Dalam: Buku Jagung. Puslitbang Tanaman Pangan. Bogor. pp. 410-426.

Tarmidi, A. R. 2004. Pengaruh pemberian ransum yang mengandung ampas tebu hasil biokonversi oleh jamur tiram putih (pleurotus ostreatus) terhadap performans domba Priangan. Jurnal Ilmiah Ternak dan Veteriner 9(3): 157-163.

Tillman, A. D., H. Hartadi, S. Reksohadiprodjo, S. Prawirokusumo dan S. Lebdososukojo. 1991. Ilmu Makanan Ternak Dasar. Gadjah Mada University Press. Yogyakarta.

Vandergrift, B. 1992. The theory and practice of mineral proteinates in the animal feed industry. In: Improving utilization while reducing pollution; New Dimension Through Biotechnology. Asia Pacific Lecture Tour. Alltech, Inc. Nicholasville. USA. pp. 133-146. 